\title{
Pemahaman Keagamaan Guru Pendidikan Agama Islam DKI Jakarta
}

\author{
Taufik Abdillah Syukur \\ Universitas Islam Negeri Syarif Hidayatullah, Jakarta, Indonesia \\ taufik.a@uinjkt.ac.id
}

\begin{abstract}
The purpose of this study was to determine the religious understanding of Islamic religious education teachers in DKI Jakarta. This study used a descriptive qualitative meth$o d$. The conclusion of this study showed that the majority of Islamic Religious Education teachers in DKI Jakarta had a contextual understanding of religion. The implication is that they still make reasoning and ratio the dominant tool in understanding Islam so it is hoped that they will always pay attention to the conditions and situations in which Islam is developed.
\end{abstract}

Keywords: DKI Jakarta, Teacher, Religious Understanding, Islamic education

\section{Abstrak}

Tujuan penelitian ini adalab untuk mengetabui pemahaman keagamaan guru Pendidikan Agama Islam di DKI Jakarta. Penelitian ini menggunakan metode kualitatif deskriptif. Kesimpulan dari penelitian ini menunjukkan bahwa guru Pendidikan Agama Islam di DKI Jakarta mayoritas masib memiliki pemahaman keagamaan kontektual. Implikasinya mereka masib menjadikan akal dan rasio sebagai alat yang dominan dalam memahami Islam sebingga diharapkan mereka akan senantiasa memperhatikan kondisi dan situasi dimana Islam itu di kembangkan.

Kata Kunci: DKI Jakarta, Guru, Pemahaman Kegamaan, Pendidikan Agama Islam Permalink/DOI: https://doi.org/10.18326/infsl3.v14i1.159-180 


\section{Pendahuluan}

Islam dianut oleh penganut yang memiliki latar belakang pendidikan, sosial, politik, kultural, kecerdasan, kecenderungan, yang berbedabeda. Keragaman latar belakang itu ternyata digunakan untuk memahami teks suci dalam Islam yaitu al-Qur'an dan al-Sunnah. Maka Islam lahir secara empiris dalam sosok dan wajah yang amat variati walaupun sumbernya sama yaitu al-Qur'an dan al-Hadits.

Pendidikan agama Islam diajarkan kepada siswa agar mereka memahami, menyakini dan mengamalkan ajaran-ajaran Islam. Maka tujuan pendidikan agama Islam ini adalah membantu para siswa agar terbina iman, ilmu, dan amal mereka sesuai dengan ajaran Islam (Alim, 2006: 6).

Yang menjadi permasalahan adalah apakah semua guru mempunyai pemahaman keagamaan yang sama dalam memahami ajaran-ajaran Islam. Karena untuk memahami ajaran-ajaran Islam bisa melalui pendekatan kontekstual atau pendekatan tekstual.

Penelitian ini bertujuan untuk mengetahui pemahaman keagamaan guru DKI Jakarta yang sedang menempuh kuliah program linieritas guru Pendidikan Agama Islam (PAI) di STAI AlHikmah Jakarta angkatan 2018/2019.

Hasil penelitian ini diharapkan dapat digunakan secara teoritis menjadi sumbangan pemikiran dan menambah wawasan tentang kajian mengenai pemahaman keagamaan guru pendidikan agama Islam yang dapat dijadikan acuan dalam penelitian, pembuatan buku dan pengajaran. Begitu juga temuan ini dapat dijadikan dasar penelitian, evaluasi dan pengembangan ilmu pengetahuan. Adapun secara praktis diharapkan penelitian ini bisa menjadi masukan bagi kepala sekolah dan dewan guru khususnya di wilayah DKI Jakarta tentang pemahaman keagamaan guru pendidikan agama Islam dan bisa menjadi informasi yang berharga kepada pemerintah DKI Jakarta khususnya dan Sekolah Tinggi Agama Islam Al-Hikmah Jakarta serta para pembaca artikel atau jurnal mengenai pemahaman keagamaan guru pendidikan agama Islam.

Peneliti tidak menemukan judul atau tulisan yang sama dengan penelitian ini. Walaupun ada penelitian terdahulu tentang 
pemahaman keagamaan tetapi substansi dan kesimpulannya berbeda dengan penelitian yang hendak peneliti teliti. Diantaranya penelitian Aeni dan Rosidin (2017) dalam jurnal Pendidikan dan Kebudayaan yang bertemakan pemahaman agama dalam bingkai kebangsaan: Studi kasus pada organisasi rohis SMA Negeri 1 Srage yang berkesimpulan bahwa nilai yang dianut untuk mewujudkan persatuan adalah toleransi dan saling menghormati. Sedangkan penelitian Muchith (2016) tentang guru Pendidikan Agama Islam profesioal berkesimpulan bahwa guru PAI setidaknya harus memiliki tiga misi yaitu mampu menunjukkan dan memahamkan Islam kepada siapapun yang ada di muka bumi ini, mampu melakukan proses pembelajaran yang ideal, serta mampu membimbing dan membina etika dan kepribadian peserta didik saat di sekolah ataupun diluar sekolah.

\section{Metode Penelitian}

Penelitian ini menggunakan metode deskriptif kualitatif, dengan menggambarkan atau melukiskan objek penelitian berdasarkan fakta-fakta yang tampak atau sebagaimana adanya (Nawawi dan Martini, 1996: 73).

Teknik pengumpulan data yang digunakan yang pertama adalah studi kepustakaan untuk mendapatkan wawancara teoritis yang komprehensif tentang pokok permasalahan serta merumuskan kerangka analisis dan pembahasan terhadap pertanyaan-pertanyaan penelitian. Tahap kedua, adalah studi lapangan meliputi studi dokumentasi yang dilakukan untuk data dan informasi mengenai pelaksanaan pendidikan dan peraturan sekolah, Tahap ketiga, peneliti berusaha mengumpulkan data sebanyak mungkin melalui wawancara yang didapat dari informasi responden berkenaan dengan kegiatan-kegiatan yang dilakukan (Moleong, 2001: 125).

Populasi dalam penelitian ini adalah seluruh mahasiswa program linieritas Guru Pendidikan Agama Islam (PAI) di STAI Al-Hikmah 
Jakarta tahun ajaran 2018/2019 yang berjumlah 20 orang.

\section{Kerangka Teori}

\section{Guru Pendidikan Agama Islam}

Undang-undang R.I. No. 14/2005 pasal 1 menjelaskan bahwa guru adalah pendidik profesional dengan tugas utama mendidik, mengajar, membimbing, mengarahkan, melatih, menilai, dan mengevaluasi peserta didik pada pendidikan anak usia dini jalur pendidikan formal, pendidikan dasar, dan pendidikan menengah.

Pendidik menurut Yusuf (1986: 53-54) adalah individu yang mampu melaksanakan tindakan mendidik dalam satu situasi pendidikan untuk mencapai tujuan pendidikan sedangkan tujuan Pendidikan Agama Islam adalah untuk membentuk peserta didik menjadi manusia yang beriman dan bertakwa kepada Tuhan Yang Maha Esa serta berakhlak mulia, hal ini berdasarkan kepada UU R.I. No.20/2003 dan Peraturan Pemerintah R.I. No.19/2005 pasal $6(1)$.

\section{Pemahaman Keagamaan}

Pemahaman adalah proses, perbuatan, cara memahami atau memahamkan (Poerwadarminta: 2006: 636). Pemahaman dalam Taksonomi Bloom meliputi penafsiran, mencontohkan, pengklasifikasian, rangkuman, membandingkan, menyimpulkan dan menjelasankan (Faisal, 2015: 104). Nurdin (2003: 105) mengartikan pemahaman merupakan kemampuan untuk menterjemahkan, menginterprestasi, mengekstrapolasi (mengungkapkan makna dibalik kalimat) dan menghubungkan di atas fakta atau konsep. Sudjiono (2001: 50) mengartikan pemahaman dengan kemampuan seseorang untuk mengerti, memahami sesuatu setelah sesuatu itu diketahui dan diingat. Pemahaman menurut Haryanto (1997: 60) didefinisikan sebagai kemampuan untuk menangkap pengertian dan sesuatu. Sedangkan "agama" adalah ajaran yang mengatur peribadahan kepada Tuhan. Jadi pemahaman keagamaan adalah proses belajar dimana seseorang mampu memahami nilai agama yang dianutnya sehingga dapat mempraktikan nilai-nilai tersebut dalam bersikap dan bertingkah laku (Menzies, 2014: 318). 
Pemahaman keagamaan disini mengandung pengertian bahwa sampai dimana kemampuan seseorang untuk mengenali atau memahami nilai agama yang mengandung nilai-nilai luhurnya serta mempraktikkan nilai-nilai tersebut dalam bersikap dan bertingkah laku. Hal ini akan terlihat dari kemampuan seseorang untuk memahami, menghayati dan mengaplikasikan nilai-nilai luhur agama yang dianutnya dalam kehidupan sehari-hari. Ia menganut agama karena menganut keyakinan agama tersebutlah yang terbaik karena itu ia berusaha menjadi penganut yang baik. Keyakinan itu ditampilkannya dalam sikap dan tingkah laku keagamaan yang mencerminkan ketaatan terhadap agamanya.

Pemahamankeagamaanyangdimaksuddisiniadalahpandangan yang mendasari seluruh aktifitas proses pemahamankeagamaan baik dalam rangka menyusun teori, perencanaan maupun pelaksanaan. Pada hakekatnya dasar pemahaman keagamaan tak lepas dari dasar pendidikan agama, karena pemahaman keagamaan dapat diperoleh melalui pendidikan agama, baik pendidikan formal maupun non formal. Oleh karena dasar itulah dasar pemahaman keagamaan tentunya tidak bisa lepas dari dasar pendidikan agama.

Dalam memahami agama Islam dapat melalui dua pendekatan, yaitu:

\section{Pendekatan Tekstual}

Disebut pendekatan tekstual karena ia menekankan signifikansi teks-teks sebagai sentra kajian Islam dengan merujuk kepada sumber-sumber suci dalam Islam, terutama al-Qur'an dan Hadits. Pendapat lain mengatakan pendekatan tekstual adalah suatu model pemahaman yang berpegang pada formal teks, berpedoman pada tradisi yang terbentuk dimasa silam dan mengikatkannya secara ketat serta menganggap ajaran islam yang mereka yakini sebagai suatu kebenaran mutlak yang tidak perlu dirubah lagi karena secara otoritatif telah dirumuskan oleh para ulama terdahulu secara final dan tuntas, mereka kurang suka dengan perubahan karena khawatir menimbulkan keresahan yang mengancam integrasi umat.

Dalam aplikasinya, pendekatan tekstual barangkali tidak menemui kendala yang cukup berarti ketika dipakai untuk melihat dimensi Islam normatif. Persoalan baru muncul ketika pendekatan 
ini dihadapkan pada realitas ibadah umat Islam yang tidak tertulis secara eksplisit, baik di dalam al-Qur'an maupun Hadits, namun kehadirannya diakui dan bahkan diamalkan oleh komunitas Muslim tertentu secara luas. Contoh yang paling nyata adalah adanya ritual tertentu dalam komunitas Muslim yang sudah mentradisi secara turun-temurun seperti slametan atau tahlilan (Channa, 2011: 393).

\section{Pendekatan Kontekstual}

Kata kontekstual berasal dari bahasa Inggris, context yaitu istilah yang berhubungan dengan kata-kata, konteks, suasana dan keadaan. Kontekstual berarti keadaan atau situasi di mana suatu kalimat atau perkataan itu di katakan. Indikator-indikator yang berada dalam situasi di mana kata-kata tersebut diucapkan ikut mempengaruhi. Misalnya kita mengatakan 'ada macam galak.' Apabila kata tersebut di ucapkan di tengah-tengah hutan, maka kata tersebut dapat menunjukkan kepada keadaan macan yang sesungguhnya. Tetapi jika kata tersebut diucapkan di supermarket, kata yang dimaksud dengan macam tersebut bisa berarti aparat keamanan atau satpam, dan yang sejenisnya. Di sini terlihat bahwa satu kata bisa mengandung arti lebih dari sati didasarkan pada situasi di mana kata tersebut diucapkan (Nata, 2001: 107).

Pendekatan kontektual dalam pemahaaman keagamaan adalah pemahaman yang penjabarannya senantiasa memperhatikan kondisi dan situasi dimana agama itu di kembangkan. Islam kontekstual adalah Islam yang di pahami sesuai dengan situasi dan kondisi di mana Islam di kembangkan. Pendekatan ini menggunakan metode yang menjadikan rasio atau akal manusia sebagai alat yang paling dominan dalam memperoleh pengetahuan atas pelbagai ajaran Islam. Maka dari itu, seluruh teks-teks wahyu harus dibedah secara kritis, logis. Rasional dan kontekstual (Nata, 2001: 108).

Pendekatan ini mengacu kepada semangat dan spirit teks bukan makna literal teks. Dengan demikian Islam akan hidup survive dan berkembang secara kreatif. Maka pintu ijtihad harus terus dibuka sehingga memungkinkan Islam mampu menjawab persoalan kemanusiaan yang terus berubah.

Guru sebagai pendidik propesional yang tugasnya mendidik, mengajar, membimbing, mengarahkan, melatih, menilai, dan 
mengevaluasi peserta didik sudah pasti memiliki kecenderungan dalam pemahaman keagamaan. Pemahaman inilah yang akan ditransfer kepada peserta didiknya. Penelitian ini menggunakan teori pemahaman keagamaan diatas, yaitu pemahaman keagamaan tektual dan kontekstual, dengan teori itulah akan dipetakan pemahaman keagamaan guru Pendidikan Agama Islam tersebut.

\section{Hasil dan Pembahasan}

\section{Zakat Fithrah dengan Uang}

Para ulama berbeda pendapat dalam memahami hadits: "Rasulullah telah mewajibkan zakat Fitrah sebanyak satu sha' kurma atau gandum atas orang muslim" (Hadits riwayat Bukhari no : 1407 dan Muslim no : 1635 dan 1646).

Sebagian ulama memahami secara kontektual, yaitu berdasarkan tujuan ditetapkannya zakat. Zakat fithrah bertujuan agar orang fakir miskin bahagia pada hari iedul fitri dan bisa memanfaatkannya. Maka, pembayaran zakat dengan uang itu lebih memudahkan di zaman sekarang, terutama di lingkungan negara industri, di mana orang tidak bermuamalah kecuali dengan uang.

Adapun sebagian ulama memahami secara tektual, yaitu tidak sah mengganti zakat fithrah dengan uang karena berdasarkan teks hadits di atas (Zuardi, 2013: 22).

Setelah dilakukan penelitian melalui wawancara dan observasi kepada beberapa guru Sekolah Dasar wilayah DKI Jakarta, maka di temui sebagian dari mereka yang berpaham keagamaannya tekstual dan sebagiannya lagi kontektual.

Adapun yang berpaham tekstual seperti pendapat Fauzi salah satu guru PAI SDN Cililitan 01 Pagi Jakarta yang mengatakan bahwa zakat fitrah itu harus dengan makanan pokok. Karena pendapat terkuat dalam fiqih adalah menggunakan makanan pokok sesuai hadits Nabi Muhammad Saw dan bisa dianalogikan dengan Qurban sekiranya diganti dengan duit pada akhirnya kurbanpun nantinya bisa lebih mashlahat dengan uang daripada daging qurban itu sendiri. Hasmawati pun demikian, bahwa zakat fithrah itu harus dengan makanan pokok sesuai perintah langsung dari Nabi Muhammad Saw dalam haditsnya. Karena kalau dengan uang itu tidak semua 
orang bisa memberi, malah nanti akan menimbulkan kesenjangan. Muhajir juga berpandangan tekstual dalam hal ini karena zakat dengan makanan pokok lebih mashlahat dan manfaat serta sesuai dengan hadits Nabi Saw. Berbeda dengan Paridah yang berpaham kontekstual yang membolehkan zakat fithrah dengan uang karena lebih mashlahah untuk fakir miskin. Beliau mengatakan bahwa saat ini kebutuhan bukan hanya makanan pokok saja tapi materi (uang) juga dibutuhkan. Bahkan Rahmadi, guru PAI SDS Kartika Jakarta membolehkan zakat fithrah dengan uang dengan alasan karena uang lebih praktis. Begitupun dengan Kamalia, yang membolehkan zakat fithrah dengan uang dengan alasan karena lebih manfaat untuk fakir miskin. Menurut penglihatannya bahwa sebagian masyarakat miskin saat ini jika menerima makanan pokok dalam jumlah yang besar maka makanan pokok tersebut (beras) dijual kembali untuk mendapatkan uang.

\section{Zakat untuk Muallaf}

Rasulullah Saw biasanya memberikan bagian zakat pada kepala suku Arab dengan tujuan untuk menarik mereka agar memeluk Islam atau mencegah mereka agar tidak membahayakan kaum Muslimin. Bagian ini diberikan pula pada orang-orang Muslim yang baru (muallaf) sehingga mereka dapat tetap memeluk Islam dengan teguh. Tetapi Umar bin Khaththab mencabut perintah yang dituliskan Abu Bakar, dikala ia masih menjadi khalifah bagi penyumbangan tanah-tanah tertentu pada sejumlah orang atas dasar bahwa Rasulullah telah memberikan bagian ini untuk memperkuat Islam, tetapi karena keadaan telah berubah, maka bagian ini tidak valid lagi. Tindakan Umar ini tampaknya bertolak belakang dengan Qur'an, tetapi sebenarnya ia mempertimbangkan situasi yang ada dan mengikuti ruh perintah Qur'an (Ridwan, 2017: 231).

Pertimbangan pribadinya membawanya pada keputusan bahwa seandainya Rasulullah hidup dalam kondisi yang sama, tentu beliau akan memutuskan hal yang serupa. Pemahaman Umar bin Khaththab dalam hal ini cenderung menggunakan pendekatan kontektual.

Dalam kasus ini, seluruh guru PAI tingkat SD di wilayah provinsi DKI Jakarta tidak sependapat dengan pratek Umar bin Khaththab 
yang meniadakan zakat untuk muallaf, yang menunjukkan bahwa mayoritas para guru berpikiran tekstual dalam masalah ini. Seperti Rahmadi mengatakan dengan tegas ketidaksetujuannya dengan pencabutan hak muallaf tersebut, karena orang yang baru masuk Islam itu perlu bimbingan. Muhajir merasakan perlunya zakat untuk muallaf karena dengan dikasih zakat, muallaf tahu bahwa agama Islam adalah agama sosial kepada sesama. Muallaf ada yang kaya dan ada juga yang miskin, Islam mengajarkan kerohiman dan kepedulian kepada siapa pun juga termasuk muallaf. Fauzi melihat bahwa muallaf itu harus dikuatkan dalam iman dan Islamnya. Semoga dengan zakat ini menjadi semakain kuat Iman Islamnya. Hasmawati juga tidak setuju dengan pencabutan muallaf dari penerima zakat karena muallaf itu harus dipedulikan. Tetapi menurut Paridah, jika ketika masuk Islam, ia sudah mapan kehidupannya, maka tidak perlu diberi zakat lagi, tetapi jika tidak mampu maka harus di bantu dengan zakat agar tidak pindah keyakinan.

\section{Hukum Potong Tangan Bagi Pencuri}

Ada seorang laki-laki mencuri barang dari Baitul Mal, tetapi Khalifah Umar bin khaththab tidak memotong tangannya. Umar membekukan hukuman pemotongan tangan pencuri tersebut karena sedang musim paceklik dan ini fakta sejarah yang masyhur. Umar sepertinya melanggar ayat suci al-Qur'an yang memerintahkan potong tangan bagi pencuri, padahal beliau sedang menatapkan hukum berdasarkan masalah yang melatarbelakanginya (Abdad, 2014: 45). Dalam kasus ini Umar menggunakan pendekatan kontekstual.

Setelah dilakukan penelitian melalui wawancara dan observasi kepada beberapa guru Sekolah Dasar di wilayah DKI Jakarta, maka di temui sebagian dari mereka yang berpaham keagamaannya tekstual dan sebagiannya lagi kontektual.

Mayoritas guru sepakat pendapat Umar bin Khathtab dalam masalah ini yang bersifat kontekstual. Seperti Rahmadi setuju dengan pendapat Umar bin Khathtab dan ia berpendapat bahwa mencuri karena lapar itu disebabkan oleh pemilik budak tersebut, maka menurutnya sangat pantas jika pemilik budak yang di hukum. Fauzi menambahkan bahwa semua keputusan hukum harus dilihat dari latar belakang masalahnya sehingga bisa memutuskan hukum 
dengan tepat. Paridah punya pandangan yang unik bahwa yang dimaafkan hanya untuk kebutuhan makan saja, jika untuk kemewahan maka para budak itu tetap harus di potong tangan. Hanya Muhajir yang berpikiran tektual dalam masalah ini dengan mengatakan bahwa semua alasan apapun kalau memang terbukti bersalah maka syariat Islam harus dijalankan karena kalau menghukumi orang dilihat dari alasannya maka orang akan banyak beralasan untuk berbuat demikian.

\section{Mengganti Kayu Siwak Dengan Dengan Sikat Gigi}

Islam adalah agama yang mencintai kebersihan, tak terkecuali kebersihan gigi. Oleh sebab itu, dalam ajaran Nabi Muhammad Saw seorang Muslim dianjurkan untuk bersiwak yang berguna untuk membersihkan gigi.

Menurut bahasa Arab, siwak berarti menggosok atau alat yang digunakan untuk itu. Nabi SAW sangat menganjurkan umatnya untuk bersiwak dalam setiap shalat. Pada masa Nabi, sebagaimana disebutkan dalam kitab-kitab fikih klasik, disebutkan bahwa orang Arab biasa menggosok gigi dengan kayu yang dikenal dengan kayu arak. Selain itu, dalam berbagai riwayat hadits, Nabi dan sahabat tidak lupa untuk mencuci kayu tersebut setelah digunakan bersiwak. Ranting kayu ini lebih lunak dan terasa nyaman di mulut.

Di Indonesia, fenomena bersiwak banyak di sekitar kita. Kayu arak ini dijual, serta dijadikan oleh-oleh jamaah haji untuk handai tolan sepulang ke Indonesia. Sebagian orang menganggap, yang disebut bersiwak adalah menggunakan kayu tersebut sewaktuwaktu, terutama sebelum shalat.

Zaman sudah berubah, masyarakat juga mengenal sikat gigi serta pasta gigi. Sikat gigi lebih mudah didapat di Indonesia, serta bisa menjangkau bagian mulut yang lebih dalam. Syekh Muhammad bin Qasim Al-Ghazi menyebutkan dalam kitabnya Fathul Qarib bahwa "Siwak adalah menggosok gigi dengan kayu arak atau sejenisnya." Dari keterangan tersebut, maka selain kayu arok pun bisa dinilai bersiwak.

Tujuan bersiwak ini adalah mulut yang bersih serta bau mulut yang sedap. Dalam interaksi kita sehari-hari, gigi kotor dan 
bau mulut tak sedap membuat tidak nyaman. Untuk menambah nilai kemuliaan saat beribadah, maka membersihkan gigi sangat dianjurkan, baik sebelum shalat, ketika akan membaca Al-Quran, dan sebagainya.

Bersiwak dengan kayu juga perlu diperhatikan. Setelah digunakan, kayu hendaknya dicuci. Lalu saat ujungnya sudah mekar, maka ia sulit untuk menjangkau sela-sela gigi. Kayu siwak yang digunakan tapi tak kunjung dicuci, tentu juga bisa menyebabkan kayu itu berbau tak sedap. Membersihkan gigi itu penting, dan meskipun tidak menggunakan kayu tetap diniatkan bersiwak agar mendapat kesunahan. Gigi bersih, nafas segar, serta mendapatkan kebaikan juga. Kalau bisa, kita juga boleh menggunakan kayu arak agar lebih menambah keutamaan.

Masyarakat kini telah mengenal sikat gigi. Sikat gigi ini mudah didapatkan, serta bisa menjangkau mulut bagian dalam. Ketika seseorang menggunakan sikat gigi, apakah itu sama dengan bersiwak dengan kayu arok?. Secara kontektual, tujuan bersiwak itu agar mulut dan gigi menjadi bersih, suci dan mendapatkan manfaat dan maslahat (Mahfudzi, 2018: 130).

Jadi jika memakai sikat gigi kemudian diniatkan bersiwak maka tetap mendapatkan kesunahan seperti dilakukan sebelum shalat atau sebelum membaca al-Qur'an.

Setelah dilakukan penelitian melalui wawancara dan observasi kepada beberapa guru Sekolah Dasar wilayah DKI Jakarta, maka di temui sebagian dari mereka yang berpaham keagamaannya tekstual dan sebagiannya lagi kontektual.

Menurut Fauzi, bahwa menggunakan pasta gigi tetap mendapat pahala sunnah dari segi hasil dan bagi yang memakai siwak akan mendapat pahala sunnah dari sisi hasil dan juga proses (karena alatnya sesuai dengan sunnah Nabi). Hal senada juga di ungkapkan oleh Hindun, bahwa Nabi Muhammad Saw itu cinta kebersihan dan untuk mendapatkan siwak yang seperti Nabi contohkan sulit di dapatkan di sini (Indonesia). Kamalia juga setuju dalam pandangan kontekstual ini, karena inti bersiwak adalah untuk membersihkan gigi. Sebagian guru ada yang berpandangan tekstual dalam hal ini, 
yang mengatakan bahwa terdapat perbedaan antara siwak dan pasta gigi, seperti Muhajir mengatakan bahwa kandungan yang ada dalam siwak itu lebih banyak manfaatnya dibanding pasta gigi diantaranya bisa menguatkan ingatan, mata menjadi terang, menguatkan badan, dan dapat menghilangkan kuman. Siwak juga banyak dan mudah di dapat di Indonesia.

\section{Isbal (Kain yang menutup mata kaki)}

Dari Abu Dzar, dari Rasulullah Saw, beliau bersabda, "Ada tiga yang tidak akan diajak bicara oleh Allah Swt pada hari kiamat, Allah Swt tidak memandang mereka, tidak mensucikan mereka dan bagi mereka azab yang menyakitkan". Rasulullah Saw mengatakannya tiga kali. Abu Dzar berkata, "Mereka itu sia-sia dan merugi. Siapakah mereka wahai Rasulullah?". Beliau menjawab, "Al-Musbil (orang yang memanjangkan jubah/kain/kaki celana menutupi mata kaki), orang yang mengungkit-ungkit pemberian dan orang yang menjual barangnya dengan sumpah dusta”. (HR. Muslim).

Dari Abu Hurairah, dari Rasulullah Saw, beliau bersabda, "Kain yang di bawah dua mata kaki, maka di dalam neraka". (HR. Bukhari).

Pendapat Ulama Memahami Hadits-Hadits Ini:

Pendapat Imam Syafi'i berpandangan bahwa Isbal adalah memanjangkan kain di bawah kedua mata kaki, hanya bagi orang yang sombong. Jika pada orang yang tidak sombong, maka makruh. Demikian disebutkan Imam Syafi'i secara nash tentang perbedaan antara orang yang memanjangkan kain karena sombong dan orang yang memanjangkan kain tetapi tidak sombong (Al-'Asqalani :1379 H: 263).

Al-'Asqalani (1379 H: 263) berkomentar tentang hadits diatas bahwa hadits-hadits itu disebutkan bahwa memanjangkan kain bagi orang-orang yang sombong adalah dosa besar. Adapun memanjangkan kain bagi yang tidak sombong, zhahir hadits ini mengandung makna haram juga, akan tetapi diikat dengan haditshadits lain yang mengandung makna sombong. Kalimat yang bersifat umum dalam kecaman tersebut mengandung makna ikatan: bagi orang yang sombong. Oleh sebab itu tidak haram menyeret 
dan memanjangkan kain jika selamat dari sifat sombong.

Al-Qaradhawi (1423: 128) memberi penjelasan tentang hadits isbal tersebut bahwa banyak pemuda Islam yang bersemangat sangat mengingkari orang lain yang tidak memendekkan pakaiannya di atas mata kaki. Bahkan mereka terlalu berlebihan dalam bersikap sampai pada tingkat menjadikan perbuatan memendekkan kaki celana sebagai syi'ar Islam atau kewajiban yang besar dalam Islam. Jika mereka melihat seorang ulama atau da'i tidak memendekkan kaki celana seperti yang mereka lakukan, mereka menuduhnya -bahkan secara terang-terangan- tidak faham agama. Jika seseorang mencukupkan dirinya hanya memahami makna zhahir dengan satu hadits saja, tanpa melihat hadits-hadits lain yang terkait dengan tema tertentu secara keseluruhan, maka orang akan mudah terjerumus dalam kekeliruan, jauh dari kebenaran dan tujuan yang dimaksud hadits Rasulullah Saw.

Memanjangkan jubah merupakan tradisi kesombongan raja-raja Romawi dan Persia masa silam. Untuk menunjukkan keangkuhan dan kesombongan mereka, maka para penguasa itu memanjangkan jubah yang ujungnya dibawa oleh para pengawal dan dayangdayang. Tradisi itu masuk juga ke dalam masyarakat Jahiliyah.

Kesimpulannya adalah bahwa sebagian ulama mengatakan bahwa isbal itu boleh asalkan tidak disertai rasa sombong, ada yang mengatakan makruh dan ada yang mengatakan haram secara mutlak (A-Qardhawi, 1423 H: 128) (Nasir, 2013: 81).

Setelah dilakukan penelitian melalui wawancara dan observasi kepada beberapa guru Sekolah Dasar wilayah DKI Jakarta, maka di temui sebagian dari mereka yang berpaham keagamaannya tekstual dan sebagiannya lagi kontektual.

Salah seorang guru SD PAI di wilayah provinsi DKI Jakarta yang bernama Rahmadi memahami hadits Nabi Muhammad Saw di atas secara tektual, alasannya kalau isbal, dikhawatirkan akan mengotori celana. Adapun mayoritas guru lainnya seperti Fauzi berpendapat bahwa boleh menggenakan celana di bawah mata kaki selama tidak sombong. Bagi yang menggenakan celana di atas mata kaki pun haram bila disertai kesombongan dan merasa paling 
benar dan suci. Hasmawati berpendapat bahwa tidak haram bagi laki-laki menggenakan pakaian sampai bawah mata kaki, karena menutup mata kaki atau tidak, kedua-duanya sama sama masih menutup aurat. Menurut Hindun bahwa batas kesombongan itu bukan dari pakaian yang dikenakannya, jika ada yang memakai di atas mata kaki atau di bawah mata kaki itu boleh boleh saja. Allah Swt menyukai keindahan, hadits Nabi jangan dipahami secara letter saja, tetapi harus dipahami berdasarkan pemahaman dari ulamaulama yang mumpuni.

\section{Tablilan}

Tahlilan menurut sebagian orang hukumnya haram karena menyerupai perayaan agama Hindu dan Budha. Begitu juga perayaan maulid Nabi, hukumnya haram, karena menyerupai perayaan kelahiran nabi Isa (Natal) dalam agama Kristen. Padahal tahlilan dan maulidan ini menurut pendapat yang lain, hanya melakukan suatu acara yang di isi didalamnya pembacaan al-Qur'an, shalawat dan do'a bersama.

Hasil penelitian yang didapati bahwa seluruh guru PAI sepakat memahami tahlilan dengan pemahaman kontektual. Seperti Fauzi mengatakan bahwa memang betul tidak ada contoh dari Nabi Muhammad Saw merupakan bid'ah, namun karena diisi dengan hal-hal yang diajarkan Nabi semisal dzikir, baca al-Qur'an dan nasehat agama sehingga menjadi bid'ah hasanah, dimana yang mengamalkan mendapat pahala. Jadi tahlilan tidak beda dengan model perkumpulan semisal pengajian, bedah buku, seminar yang tak ada contohnya dari Nabi Saw. Pendapat ini senada dengan pendapatnya Muhajir yang berpendapat bahwa yang yang tidak dicontohkan tidak selalu menjadi bid'ah. Bid'ah ada dua, ada basanab dan sayyi'ah, dan tahlilan itu bid'ah hasanah, karena tujuannya baik yaitu mendoakan orang yang telah wafat dan menghibur kesedihan atas orang yang ditinggalkan dan itu tradisi tidak bertentangan dengan syariat Islam. Hasmawati berpendapat bahwa selama ajarannya tidak menyimpang dari Islam maka tahlilan itu boleh saja dilakukan. Karena dengan adanya tahlilan bisa menambah kerukunan umat Islam dan dapat menjaga silaturahmi. Menurut Rahmadi tahlilan itu baik untuk taqorrub (mendekatkan 
diri) kepada Allah Swt. Hindun juga berpendapat bahwa tahlilan memang tidak diajarkan Rasulullah Saw akan tetapi Nabi menganjurkan kita untuk banyak banyak mengucapkan kalimat thayibah dan tahlilan adalah doa dan ucapan-ucapan kalimat thayibah tersebut

\section{Saksi Perzinaan}

Sebagian ulama berpendapat bahwa jika jumlah saksi dalam kasus zina kurang dari empat orang maka persaksian mereka tidak diterima. Akan tetapi Syaltut (1980: 345) berpendapat bahwa jika tidak memungkinkan hadir empat orang saksi dalam kasus zina, maka bukti-bukti lain bisa digunakan hakim dalam membuat keputusan. Pemahaman Syaltut ini termasuk pemahaman kontektual.

Setelah dilakukan penelitian melalui wawancara dan observasi kepada beberapa guru Sekolah Dasar wilayah DKI Jakarta, maka di temui sebagian dari mereka yang berpaham keagamaannya tekstual dan sebagiannya lagi kontektual.

Pendapat Syaltut ini diamini oleh sebagian guru PAI ini, seperti Paridah menyetujui pendapat Syaltut karena zaman tekhnologi sudah canggih dan dapat disaksikan oleh orang banyak. Adapun kebenaran sebuah video dapat memanggil ahli IT sehingga dapat melihat jelas kebenarannya. Muhajir sangat setuju dengan pendapat Syaltut, karena dengan seperti itu, akan memberikan efek jera bagi orang yang melakukan zina tersebut dan menjaga kehormatan bagi pihak yang dirugikan. Bahkan menurut Hindun bahwa bukti video adalah bukti yang kuat. Bahkan kalau dengan saksi satu orang yang sebagai saksi kunci dengan bukti yang kuat juga maka itu sah-sah saja. Tapi berbeda dengan Fauzi yang berpendapat bahwa saksi zina harus empat orang saksi. Karena tuduhan zina terhadap seseorang merupakan dosa besar, maka dibutuhkan kehati-hatian dalam tuduhan. Maka menuduh zina itu harus disaksikan empat orang, jika tidak mencapai empat orang maka tidak sah.

\section{Bunga Bank}

Masalah bunga bank ini masih menjadi perbedaan pendapat di kalangan ulama. Karena gaya pikir mereka yang tekstual atau kontekstual. Seperti Syaltut (1980: 391) yang berpendapat bahwa 
prinsip syari'at Islam adalah tercapainya mashlabah, terlindunginya aturan dan hak-hak serta meningkatnya taraf hidup. Maka dari itu ia menghalalkan bunga tabungan karena dipandang memberikan kemashlahatan dan tidak menimbulkan kemudharatan, baik yang menabung atau yang menerima tabungan, kedua-duanya mendatangkan kebaikan. Didalamnya tidak terdapat orang yang menganiaya dan teraniaya, dengan kata lain tidak ada unsur pemerasan atau pemaksaan. Laba yang diberikan oleh tabungan adalah sebagai suatu daya tarik saja. Pendapat Syaltut ini berbeda dengan kalangan ulama Mesir saat itu yang menyatakan bahwa keuntungan yang diberikan oleh Bank adalah haram.

Setelah dilakukan penelitian melalui wawancara dan observasi kepada beberapa guru Sekolah Dasar wilayah DKI Jakarta, maka di temui sebagian dari mereka yang berpaham keagamaannya tekstual dan sebagiannya lagi kontektual.

Fauzi sepakat dengan mayoritas ulama Mesir yang berpendapat bahwa konsep dasar riba adalah sesuatu yang bertambah. Allah Swt menghalalkan jual beli artinya bila pihak bank memutar uang nasabah untuk jual beli maka itu sistem bagi hasil dan itu boleh tapi kalau bunga bukan dari sistem jual beli makanya menjadi riba'. Muhajir juga tidak setuju dengan pendapat Syaltut. Alasannya bahwa di satu sisi mungkin tidak ada yang dirugikan, tetapi disisi lain, nanti akan banyak orang yang menghalalkan riba dalam suatu transaksi padahal jelas bahwa riba termasuk dosa besar. Tetapi pendapat Syaltut ini banyak memperoleh dukungan dari guru PAI yang lainnya seperti Kamalia berpendapat bahwa zaman sudah semakin berkembang dan modern. Pihak Bank dan nasabah tidak ada unsur paksaan di kedua belah pihak. Di samping itu, menurut Hasmawati, ada unsur kemashlahatan dan tidak menimbulkan kemudaratan diantara kedua belah pihak.

\section{Kesaksian Wanita}

Ketika memahami ayat al-Qur'an Surat al-Baqarah (2) ayat 282, Allah Swt berfirman: "persaksikan dengan dua orang saksi dari orang lelaki, jika tidak ada dua orang lelaki, maka boleh seorang lelaki dan dua orang perempuan, " maka terkesan ada ketidaksetaraan antara laki-laki dan wanita, bahwa wanita itu lebih 
rendah dari laki-laki, karena kesaksian seorang wanita bernilai separuh dari kesaksian laki-laki.

Bahkan kesaksian wanita tidak diterima dalam kasus pidana seperti qishash dan hudud. Kesaksian wanita baru diakui tanpa didampingi kesaksian laki-laki, hanya kasus yang biasa diketahui wanita saja seperti masalah haid, peristiwa kelahiran dan rada'ah saja (Al-Jauziyyah, 1961: 92-93). Maka Syaltut (1980: 239-240) berpendapat bahwa kesaksian seorang wanita itu sama dan setara nilainya dengan kesaksian seorang laki-laki. Pendapat ini tentu saja berbeda dengan pendapat yang selama ini berkembang dikalangan fuqaha.

Setelah dilakukan penelitian melalui wawancara dan observasi kepada beberapa guru Sekolah Dasar wilayah DKI Jakarta, maka di temui sebagian dari mereka yang berpaham keagamaannya tekstual dan sebagiannya lagi kontektual.

Muhajir berpendapat bahwa ia setuju dengan pendapat Mahmud Syaltut karena keduanya, baik laki-laki maupun perempuan mempunyai hak yang sama. Hindun berpendapat bahwa wanita dan laki-laki memang tidak sebanding namun jika tidak ada yang menjadi saksi lain maka tidak mengapa, asalkan wanita tersebut saksi yang dapat dipercaya. Hasmawati berpendapat bahwa persaksian itu tidak perlu memandang jenis kelamin, jadi laki-laki atau perempuan bisa saja untuk dijadikan saksi asalkan kesaksiannya itu sesuai dengan kenyataan dan sesuai dengan apa yang diucapkan. Tetapi Fauzi, tidak sepakat dengan pendapat Syaltut, alasannya karena secara psikologis lelaki dan wanita itu berbeda. Imam alGhazali berpendapat bahwa laki laki itu akalnya sembilan dan nafsunya satu, sementara perempuan itu akalnya satu dan nafsunya sembilan. Mungkin karena faktor inilah al-Qur'an membandingkan satu laki-laki dengan dua perempuan. Paridah juga mengatakan hal yang sama, bahwa hukum harus mengikuti firman Allah. Perempuan terkadang mengedepankan perasaan dibanding fikiran. Jika dua perempuan menjadi saksi maka dapat membantu untuk menguatkan alasan perempuan yang satunya lagi. Bahkan menurut Rahmadi, wanita itu bersifat bengkok atau mudah dipengaruhi karena terbuat dari tulang rusuk Nabi Adam AS, maksudnya adalah 
wanita itu kurang tegar dan perasaannya mudah terbawa. Kamalia juga berpendapat bahwa wanita selalu mengutamakan perasaannya dalam memberikan kesaksian dan laki-laki lebih kuat dari seorang wanita.

\section{Kasus Bani Quraidhoh}

Fenomena tekstualis dan kontekstualis dalam pemahaman teks kemunculannya telah ada semenjak Nabi saw masih hidup. Hal ini dapat ditelusuri dari peristiwa kontroversi shalat ashar ketika nabi mengutus para sahabatnya ke perkampungan Bani Quraidzah.

Ketika Nabi memerintahkan "jangan kalian shalat Ashar, kecuali di perkampungan Bani Quraidhoh" (HR. Bukhari no : 894 dan Muslim dari Ibnu Umar no: 3317), sebagian sahabat memahami perintah Nabi (Hadits) tersebut secara kontekstual yaitu dengan menangkap maksud dan tujuan Nabi agar mempercepat perjalanan, tetapi jika belum sampai tujuan dan waktu Ashar hampir habis maka tetaplah shalat diwaktunya walaupun masih dalam perjalanan. Sedangkan sebagian shabahat yang lain melakukan shalat Ashar di perkampungan Bani Quraidhah meski hari telah gelap, karena sebagian shahabat ini memahami perintah Nabi secara tekstual (Hariono, 2017: 19).

Setelah dilakukan penelitian melalui wawancara dan observasi kepada beberapa guru Sekolah Dasar wilayah DKI Jakarta, maka di temui sebagian dari mereka yang berpaham keagamaannya tekstual dan sebagiannya lagi kontektual.

Fauzi memilih kecenderungannya kepada ke kelompok A, walau Nabi Saw memerintahkan shalat Ashar di Bani Quraidzah, akan tetapi ada aturan yang itupun adalah ajaran Nabi Muhammad Saw bahwa shalat itu harus pada waktunya. Karenanya walau dia tidak shalat Ashar di Bani Quraidzah tetap disebut sebagai orang yang taat pada Nabi Muhammad Saw. Begitu juga dengan Hindun, yang lebih cenderung ke kelompok A yang melaksanakan sholat dipertengahan jalan walaupun belum sampai Bani Quraidzah. Karena menurutnya orang yang sholat di luar waktu atau melewati waktu adalah termasuk orang yang lalai dan merugi. Begitupun Muhajir yang lebih cenderung kepada kelompok A, karena sholat yang baik adalah sholat di awal waktu. Berbeda dengan Hasmawati 
yang lebih cenderung kepada kelompok B, dengan alasan karena itu perintah dari imam mereka yaitu Nabi Muhammad Saw. Paridah juga cenderung kepada kelompok B, karena Ashar bisa bisa di lakukan di di Bani Quraidzah dan ini bisa dijadikan sebagai pembelajaran.

Setelah dilakukan penelitian, karena penelitan ini bersifat deskriptif kualitatif, maka selanjutnya peneliti akan menggambarkan hasil penelitian berdasarkan fakta-fakta yang tampak atau sebagaimana adanya bahwa dalam masalah zakat fithrah dengan uang, melalui penelitian ini didapati bahwa guru yang memahami zakat fithrah harus dengan makanan pokok (tekstual) jumlahnya lebih banyak dibanding guru yang membolehkan zakat fithrah dengan uang (kontekstual). Dengan demikian bahwa guru yang berfaham tekstual dalam masalah ini lebih banyak dibanding guru yang berpaham kontektual.

Kemudian kasus zakat untuk muallaf, para guru sepakat bahwa zakat fithrah boleh di diberikan kepada muallaf (orang yang baru masuk Islam) yang menandakan bahwa seluruh guru berpaham tektualis dalam masalah ini karena berdasarkan teks firman Allah Swt pada surat at-Taubah ayat 60. Kebalikannya dengan kasus zakat untuk muallaf, bahwa pada kasus hukum potong tangan bagi pencuri memperlihatkan bahwa hampir seluruh guru berpikir kontekstual karena menyetujui ijtihad Umar bin Khaththab yang tidak memotong tangan pencuri saat kondisi sedang tidak dalam kondisi normal.

Kemudian, tiga orang guru berpandangan tekstual dalam masalah mengganti siwak dengan pasta gigi. Mereka berpendapat bahwa siwak tidak sama dengan pasta gigi karena ada kandungan siwak yang manfaatnya lebih banyak dibanding pasta gigi. Sedangkan empat orang guru berpandangan kontekstual bahwa bisa saja siwak yang sulit dicari di Indonesia di ganti dengan pasta gigi dan memiliki pahala yang sama dengan siwak. Dalam memahami masalah isbal, mayoritas guru memiliki paham kontektual, yakni seseorang boleh saja memakan celana atau kain menutupi mata kaki asalkan jangan diiringi dengan sifat sombong.

Dalam masalah tahlilan, seluruh guru membolehkan praktik tahlilan, karena walaupun tidak ada contohnya dari Nabi 
Muhammad Saw akan tetapi seluruh amalannya mengandung nilai pahala. Dalam kasus saksi perzinaan, empat dari tujuh guru berpikir kontekstual dengan berpendapat bahwa manakala buktibukti sudah cukup kuat tentang adanya perzinaan, maka tanpa empat orang saksi pun bisa dijatuhkan hukuman. Mayoritas para guru berpaham kontektual karena membolehkan bunga tabungan. Karena dipandang memberikan kemashlahatan, tidak menimbulkan kemudharatan, tidak terdapat orang yang menganiaya dan teraniaya, dengan kata lain tidak ada unsur pemerasan atau pemaksaan. Laba yang diberikan oleh tabungan adalah sebagai suatu daya tarik saja. Empat dari tujuh guru berpaham tekstual dalam memahami ayat tentang kesaksian wanita, alasannya karena secara psikologis lelaki dan wanita itu berbeda. Dan yang terakhir, yaitu dalam kasus Bani Quraidzoh, mayoritas guru berpaham kontekstual, dalam hal ini mereka sepakat dengan para shahabat yang memilih untuk shalat di jalan, karena esesnsi dari perintah Nabi Muhammad adalah agar para shahabat mempercepat perjalanan ke Bani Quraidzah. Tetapi jika belum sampai juga padahal sudah mempercepat langkah, maka alangkah baiknya shalat ashar di waktunya sebelum sampai Bani Quaraidzah.

\section{Kesimpulan}

Kesimpulan dari penelitian ini menunjukkan bahwa guru Pendidikan Agama Islam di DKI Jakarta mayoritas memiliki pemahaman keagamaan kontektual. Implikasinya mereka masih menjadikan akal dan rasio sebagai alat yang dominan dalam memahami Islam sehingga diharapkan mereka akan senantiasa memperhatikan kondisi dan situasi dimana Islam itu di kembangkan. 


\section{Daftar Pustaka}

Abdad, MZ. 2014. Ijtihad Umar Ibn Al-Khattàb:Telaah Sosio-Historis Ataspemikiran Hukum Islam. Istinbath: Jurnal Hukum Islam IAIN Mataram. Vol. 13, No. 1: 37-50.

Aeni, Nurul \& Rosidin. 2017. Pemahaman Agama Dalam Bingkai Kebangsaan: Studi Kasus pada Organisasi Rohis SMA Negeri 1 Srage. Jurnal Pendidikan dan Kebudayaan. Vol. 2 No. 2: $135-149$.

Alim, Muhammad. 2006. Pendidikan Agama Islam Upaya Pembentukan Pemikiran dan Kepribadian Muslim. Bandung: PT Remaja Rosdakarya.

Al-'Asqalani, Ibnu Hajar. 1379 H. Fath al-Bari Syarh Shahih alBukhari. Juz X. Beirut: Dar al-Ma'rifah.

Al-Jauziyyah, Ibn Qayyim. 1961. Al-Turuq al-Hukmiyyah fi al-Siasah al-Syar'iyyah. Kairo : al-Mu'assasah al-Arabiyyah li al-Tiba'ah wa al-Nasyr.

Al-Qaradhawi, Yusuf. 1423 H. Kaifa Nata'amal Ma'a as-Sunnah an-Nabawiyyah, Cairo; Dar asy-Syuruq.

Channa, Liliek. 2011. Memahami Makna Hadis Secara Tekstual dan Kontekstual. Jurnal Ulumuna. Volume XV Nomor 2: 391-414.

Departemen Pendidikan dan Kebudayaan. 2003. Kamus Besar Bahasa Indonesia. Jakarta : Balai Pustaka.

Faisal. 2015. Mengintegrasikan Revisis Taksonomi Bloom Kedalam Pembelajaran Biologi. Jurnal Sainsmat. Vol. IV, No. 2: 102-111

Hariono, Duwi. 2017. Pemahaman Hadith, (Definisi, Aliran, dan Afilisasi). Jurnal Keislaman dan Kebudayaan, Vol. 11, No. 1: 131-138.

Haryanto. 1997. Perencanaan Pengajaran. Jakarta: Rineka Cipta.

Mahfudzi. 2018. Peran Islam Terhadap Praktek Ekonomi Dalam Dam Haji. Jurnal Kordinat Vol. XVII No.1: 129-146.

Menzies, Allan. 2014. Sejarah Agama Agama. Yogyakarta : Forum. 
Moleong, Lexy J. 2001. Metodologi Penelitian Kualitatif. Bandung: Remaja Rosdakarya.

Muchith, Saekan 2016. Guru PAI Yang Profesional. Jurnal Quality, Vol. 4, No. 2: 217-235.

Nasir, Muhammad. 2013. Kontroversi Hadis-Hadis Tentang Isbal (Telaah Kritis Sanad dan Matan Hadis serta Metode Penyelesainnya). Jurnal Farabi, Vol. 10 No. 1: 81-98.

Nata, Abuddin. 2001. Peta Keragaman Pemikiran Islam di Indonesia. Jakarta: PT. RajaGrafindo Persada. Ed. 1. Cet. 2.

Nawawi, Hadari \& Martini. 1996. Penelitian Terapan, Yogyakarta: Gajah mada University Press, Cet. 2.

Nurdin, Syafrudin. 2003. Guru Profesional dan Implementasi Kurikulum, Jakarta: Ciputat Press.

Poerwadarminta. 2006. Kamus Umum Bahasa Indonesia, Jakarta: Balai Pustaka.

Ridwan, Muhammad. 2017. Implementasi Syariat Islam:Telaah atas Praktik Ijtihad Umar bin Khattab. Tsaqafah-Jurnal Peradaban Islam. Vol. 13, No. 2: 231-254.

Sudijono, Anas. 2011. Pengantar Evaluasi Pendidikan. Jakarta: Rajawali Pers.

Sukardi. 2003. Metode Penelitian Pendidikan, Kompetensi dan Prakteknya. Jakarta: Bumi Aksara.

Syaltut, Mahmud. 1980. al-lslam Aqidah wa al-Syari'ah. Kairo: Dar al-Syuruq.

Yusuf, Muri. 1986. Pengantar Ilmu Pendidikan, Jakarta: Ghalia Indonesia.

Zuardi, Hanafi. 2013. Optimalisasi Zakat Dalam Ekonomi Islam. Adzkiya: Jurnal Hukum dan Ekonomi Syariah. Vol. 1 No. 1: $16-34$ 